\title{
APRENDER A HABLAR Y ESCRIBIR EN CASTELLANO EN EL VIRREINATO DEL PERÚ: LA CONSTRUCCIÓN DE IDENTIDADES TRANSCULTURALES EN LOS DIBUJOS DIDÁCTICOS DE GUAMÁN POMA DE AYALA (c. 1616)
}

\author{
Learning to Speak and Write in Castilian Spanish in the \\ Viceroyalty of Peru: The Construction of Transcultural Identities \\ in the Didactic Drawings of Guamán Poma de Ayala (c. 1616) \\ Delfín ORTEGa SÁNCHEZ ${ }^{1}$ \\ Universidad de Burgos
}

\section{Resumen}

La investigación analiza los procesos de transculturación y conformación de la identidad en los dibujos didácticos de la Primer nueva corónica y buen gobierno de Guamán Poma de Ayala (c. 1616). Entendidos como actos dialógicos pluriculturales entre las visiones cosmológicas andinas y los nuevos sistemas de codificación cultural europeos, el trabajo estudia la iconografía en torno a la educación colonial y al indio ladino, a partir de las relaciones establecidas entre espacio, icono y símbolo. Con este fin, diseñamos un instrumento de vaciado de datos y análisis categorial de lectura topológica, con el objeto de proporcionar claves de interpretación iconográficas válidas en los dibujos didácticos. La cuidadosa configuración iconográfica de los dibujos de Guamán representa el resultado del conocimiento consciente de la utilidad y potencial didáctico, persuasivo, propagandístico y mnemotécnico de la imagen. El aprendizaje de la lectura y escritura de la lengua castellana se presenta así como uno de los instrumentos para alcanzar la supervivencia en el orden colonial y la defensa de los nativos ante las autoridades virreinales. Guamán sitúa en la lengua, la escritura y la educación colonial el germen del orden político y administrativo. El dominio de la escritura fija la base para la conformación de una identidad múltiple y transcultural no excluyente, que evidencia la comunicación dialógica y efectiva de una memoria cultu-

1 Doctor en Didáctica de las Ciencias Sociales y en Historia de América. Profesor e investigador de la Facultad de Educación de la Universidad de Burgos. Correo electrónico: dosanchez@ubu.es. Fecha de recepción del artículo: 17 de abril de 2016. Fecha de aceptación y versión final: 30 de junio de 2016.

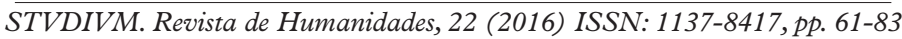


ral, resultado de la negociación de dos identidades, la propia de la conciencia del pasado prehispánico y su recodificación ordenada en los patrones culturales europeos.

Palabras clave: historia de la educación, Guamán Poma de Ayala, identidades culturales, imagen didáctica

\section{Abstract}

The investigation analyzes the processes of transculturation and conformation of the identity in the didactic drawings of Primer nueva crónica y buen gobierno, by Guamán Poma de Ayala (c. 1616). Seen as multicultural dialogues between the cosmological Andean visions and the new European systems of cultural codification, the study analyzes the iconography concerning the colonial education and to the indio ladino, from the relations established between space, icon and symbol. With this intention, we design an instrument of emptying of information and categorial analysis of topological reading, in order iconographic valid keys of interpretation provide in the didactic drawings. The careful iconographic configuration of Guamán's drawings represents the result of the conscious knowledge of the usefulness and didactic, persuasive, propagandistic and mnemonic potential of the image. The learning of the reading and writing of the Castilian language appears as well as one of the instruments to get the survival in the colonial order and the defense of the native. Guamán places in the language, the writing and the colonial education the germ of the political and administrative order. The domain of the writing fixes the base for the conformation of a multiple identity and transcultural not exclusive, that demonstrates the effective communication of a cultural memory, result of the negotiation of two identities, the own one of the conscience of the pre-Hispanic past and its recodification arranged in the European thought.

Key words: history of education, Guamán Poma de Ayala, cultural identities, didactic image

\section{Guamán Poma de Ayala y \\ LA PRIMER NUEVA CORÓNICA Y BUEN GOBIERNo}

Pocas son las noticias biográficas sobre Felipe Guamán Poma de Ayala, la mayoría referidas por él mismo a lo largo de su manuscrito. Posiblemente, naciera en torno a 1535 en San Cristóbal de Suntunto (Sondondo), región de Huanuco o Lucanas, y moriría hacia el año 1616. Según sus confesiones, fue heredero de las dinastías reales inca y yarovilca; su madre, Juana Curi Ocllo, era la hija menor del décimo inca Túpac Yupanqui, y su padre, Martín Guamán Malqui de Ayala, descendía de los yarovilca allauca huánucos, señores del Chinchaysuyu e impulsores de la unidad imperial pre-incaica. 
Junto a la competencia lingüística en su lengua materna, un dialecto del runa simi, Guamán adquiere la propia de la lengua castellana. Según sus notas biográficas, conoce otros dialectos y lenguas nativas: «Escogí la lengua e fracis castellana, aymara, colla, puquina conde, yunga, quichina ynga, uanca, chinchaysuyo, yauyo, andesuyo, condesuyo, collasuyo, cañari, cayanpi, quito» (Poma de Ayala, 2001: 10). Es posible que recibiera de su hermanastro Martín de Ayala, presbítero y ermitaño mestizo hijo de Juana Curi Ocllo y del capitán Luis de Ávalos de Ayala, ${ }^{2}$ formación humanística y que la completara prestando servicios a la administración y jurisprudencia colonial como intérprete, teniente de corregidor, ayudante de visitadores eclesiásticos, instructor y secretario. Esta privilegiada posición le posibilitaría el acceso a las bibliotecas y centros educativos de elite para mestizos e hijos de caciques, y el conocimiento de las nuevas codificaciones culturales de los catálogos de preguntas, formuladas para las visitas, los confesionarios, los expedientes y protocolos judiciales y otras formas de documentación administrativa como inventarios o calendarios (Fritz 2005: 91).

La controvertida Primer nueva corónica y buen gobierno (c. 1616) ${ }^{3}$ —en adelante, NC (cód. GKS $22324^{\circ}$, Biblioteca Real de Dinamarca, Copenhague) — de Guamán Poma de Ayala puede considerarse el texto verbo-visual más importante de la producción intelectual novohispana. Entre sus finalidades, fue concebida para la denuncia documental de los desastres y abusos españoles en el virreinato peruano, sirviendo también de soporte a la descripción de su propuesta de «buen gobierno» ${ }^{4}$ articulada en modelos ideales de comportamiento, moral y virtud, a partir de

2 Según noticias del cronista, su padre prestó servicios a este capitán en la Huarinapampa (Collao), donde le salvó la vida. En agradecimiento, el español le otorgaría el apellido «de Ayala».

3 En 1616 el cronista incorporó adiciones y enmiendas a la primera versión del manuscrito, razón por la que puede proponerse esta fecha como la más cierta para la edición final de la obra (Adorno y Boserup 2003: 48-49). Acerca del carácter controvertido de la crónica, pueden consultarse los estudios de Adorno (2000) y Cantú (2001).

4 Entre los remedios al desorden de la administración colonial, propone el autor: los delegados reales deberán ser dos, el virrey y el Consejo Real; cada provincia deberá ser administrada por un cacique nativo; deberá reconocerse el privilegio natural de los antiguos señores; se permitirá el ordenamiento de sacerdotes nativos; indígenas y españoles habrán de separarse en distintos poblados, evitando el mestizaje y sus devastadores efectos sobre la composición racial, étnica y social del Perú andino, origen de la desestructuración de las jerarquías tradicionales, y fomentando la repoblación de las comunidades indígenas; se prohibirá la violación de las indias por los sacerdotes; y se nombrará a un visitador general, encargado de controlar el sistema (Ortega Sánchez 2011a). 
su particular hibridación de la cultura didáctico-visual europea, ${ }^{5}$ la yarovilca y la inca.

La NC, hallada por el investigador alemán Richard Pietschmann en la Colección Real de Copenhague en 1908, se compone de 1189 folios en cuya redacción se invertiría un período de pocos años, frente a los veinte o treinta que dice el cronista haber investigado (Serna 2012: 113). Su complejidad historiográfica y narrativa aleja al manuscrito de la adhesión a cualquier tradición cultural específica, dificultando su filiación a la crónica de Indias, justificada por su afán cronológico, la utilización de testigos oculares y la intención moralizadora (González Boixo 1999). De igual manera, la presentación de una alternativa política al mal gobierno de la monarquía española en el Virreinato del Perú (Poma de Ayala 2001: 438-490) aproxima el texto de Guamán al memorial arbitrista (Pérez 1996: 141-188; Poma de Ayala 2001: 671) pero también a los tratados políticos de derecho y educación de príncipes (López-Baralt 1988: 481);6 a la carta; al manual de predicadores (Poma de Ayala 2001: 974-999), mediante el uso de la técnica didáctica de diálogo cruzado de preguntarespuesta («entrevista» entre predicador y neófito), habitual en los manuales de evangelización, y la incorporación de más de una docena de sermones; ${ }^{7}$ y a la crónica india, género iniciado por la primera generación de cronistas amerindios Castro Tito Cusi Yupanqui y Juan de Santa Cruz Pachacuti, característico por la asunción de la actitud fatalista, la inexac-

5 El andino se suma a la vocación didáctica de la imagen de la Europa de los siglos XVI y XVII, expresada, de forma privilegiada, en el emblema, estructura combinada de textos e imágenes de realidades abstractas y conceptuales de tiempos y espacios indeterminados. La estructura empleada por su creador Alciato, y adaptada por el andino (Ortega Sánchez 2011b), contemplaba una disposición tripartita: 1) el motto, lema o inscriptio, nomina la composición, 2) la pictura o ilustración, núcleo visual del emblema y 3) el epigrama o subscriptio, comentario encargado de desvelar el significado de la imagen simbólica propuesta.

6 La literatura de regimine principum, perfilada como género en torno al siglo XVI, se caracterizó por la actitud personal con la que los autores se dirigían a los gobernantes, fuentes, para ellos, del bien o del mal de los reinos, el énfasis en la educación y la necesaria representación del príncipe como modelo de virtud (Galino, 1948).

7 Véase Adorno 1991b y 1991c; Poma de Ayala 2001: 11, 52, 56, 62, 78, 144, 369, 490, 573, $672,673,714,725,751,832,922,972,998,1085$, con probable influencia de los sermonarios y catecismos producidos en Lima tras la celebración del Tercer Concilio Limense (1583). De particular importancia sería para nuestro autor el Tercero Catecismo y exposición de la doctrina por sermones, en el que participaría de forma muy activa el jesuita José de Acosta, y cuyas recomendaciones sigue al pie de la letra: adecuación del texto a los distintos públicos, uso de repeticiones para la fijación del mensaje en la memoria, y empleo de un estilo claro o de un tono conversacional.

STVDIVM. Revista de Humanidades, 22 (2016) ISSN: 1137-8417, pp. 61-83 
titud histórica ${ }^{8}$ y la confusión lingüística quechua-castellano (Porras 1999: 41), tal y como muestran los errores de transferencia e hipercorrecciones lingüísticas del manuscrito de Guamán.

A pesar de esta heterogeneidad narrativa, la NC se adapta a la preceptiva de la historiografía europea coetánea, incorporando la responsabilidad del sujeto social como acicate del cambio histórico, de la génesis y devenir de los Estados; la cuidadosa observación de la naturaleza con detalladas descripciones etnográficas del pasado preincaico e inca; y la adopción de la perspectiva providencialista, trazada desde América hacia el Viejo Mundo. En esta línea, la $N C$ aborda la historia de la colonia desde parámetros ético-legales mediante la esclavitud, la libertad o la injusticia en los diversos enunciados que la conforman.

Atendiendo a su diversidad temática, es posible fragmentar el manuscrito en tres partes: la Nueva Crónica y la Historia de la Conquista, finalizadas entre 1612 y 1613, y el Buen Gobierno, entre 1613 y 1614 (Pezzuto 2006: 227). La primera y segunda parte desarrollan la historia del Tawantinsuyu, desde la creación cristianizada del mundo hasta la conquista del Perú y las guerras civiles, reinterpretando «la cosmovisión andina con la aplicación de términos cristianos a conceptos precoloniales» (Fritz 2005: 93), esto es, la reforma del Universo según la cosmogonía cuatripartita andina en la que cada parte se hallará gobernada por un príncipe, y en la que el emperador español reuniría en su persona el poder del «nuevo inca de una cristiandad andina» (Ortega 1988: 371-372). En ambas, la imagen del inca se perfila por la ilegitimidad de su gobierno, el despotismo y la crueldad. La llegada de los españoles, asevera Guamán, sería necesaria en cuanto que pondría fin a la idolatría inca, y la conquista, aceptada. El imperio español es interpretado, por tanto, como instrumento de los designios divinos, y la conquista como proceso de legitimación divina (Serna 2012: 114 y 118). ${ }^{9}$ En esta reconducción del desorden idolátrico incaico

8 Prueba de ello, por ejemplo, es la confusión entre dos hechos: el asombro del conquistador Pedro de Candía ante las riquezas de Huayna Cápac en Tumbes durante la expedición de 1527, suceso documentado, y el supuesto encuentro de ambos en el Cuzco (Poma de Ayala 2001: 371).

9 El autor afirma la existencia de una etapa de pre-evangelización prehispánica, encabezada por el apóstol San Bartolomé. Es en este período, abordado en la narración de las cuatro edades pre-incaicas, donde Guamán atribuye el orden y la asunción de los valores cristianos a la sociedad andina. «(...) Y fue enbiado el Espíritu Santo a los sanctos apóstoles y se rrepartió a todo el mundo los apóstoles. Y ací bino San Bartolomé a este rreyno de las Yndias en este tienpo de Chinbo Urma (segunda reina, coya)». (Poma de Ayala 2001: 123). 
también proclama la labor evangelizadora, especialmente de las órdenes franciscana y jesuita (Poma de Ayala 2001: 673-674). Esta idea providencialista motivará la valoración del Nuevo Mundo como encrucijada del Cristianismo.

Finalmente, con el título Buen gobierno, el andino relaciona la historia de los primeros años del siglo XVII, fundamentalmente entre 1608 y 1613, y analiza la vida colonial en la administración del Virreinato. Presentado en calidad de consejero real ante el rey de España, Felipe III, Guamán redacta e ilustra esta tercera parte como un compendioso alegato de denuncias de los abusos de corregidores, religiosos (excepción hecha a franciscanos y, sobre todo, a jesuitas), encomenderos, falsos licenciados y criollos haraganes; de la idolatría, la codicia de los caciques y la lujuria de los clérigos. Junto a la valoración positiva de la figura del monarca y de ciertas autoridades virreinales, pone en marcha su propuesta de reforma (Serna 2012: 114).

\section{LA ICONOGRAFÍA DE LA NUEVA CRÓNICA $Y$ BUEN GOBIERNO}

La linealidad y limpieza de los dibujos a pluma y tinta sobre papel de la $N C$, sin referentes en la iconografía europea, denotan el conocimiento del grabado europeo, aunque destaca su especial originalidad y estilo compositivo, vinculado al arte mural indígena del momento. Su aparente sencillez y carácter naturalista, por el que se representan personas, hechos y objetos concretos, sin embargo, incluye contenidos donde lo conceptual sobrepasa lo figurativo, ofreciendo dos lecturas iconográficas: una externa, de naturaleza descriptiva, destinada al lector-observador europeo, y otra indígena interna.

En relación con la primera de las lecturas, las imágenes de la obra de Guamán se aproximan al modelo estructural y conceptual de la emblemática política europea, por su efectivo potencial didáctico, mnemotécnico y propagandístico, incorporando imágenes didácticas discursivas a las narrativas textuales (López-Baralt 1988; Ortega Sánchez 2009: 42-63, 2010 y 2011a: 57-76). Sin embargo, de acuerdo con los propósitos del autor, la extensa denuncia subvertirá sus funciones: sustituye la noción política del emblema, entendida como escaparate de la buena soberanía, imagen habitual en las celebraciones cívicas, por la de tiranía en la administración colonial; trasmuta la noción ideológica, figurada en la representación de fábulas y mitos clásicos a otra más realista, descriptiva y delimitada en 
tiempos y espacios concretos; por último, utiliza la noción moral para vehicular y argumentar su protesta/propuesta de «buen gobierno» desde una perspectiva organicista del Estado. En este sentido, el autor no trata de recordar y/o teorizar sobre las virtudes del príncipe cristiano, cabeza del Estado, en el buen funcionamiento de su gobierno, sino de dirigirlas hacia los agentes políticos y religiosos más próximos al nativo, cuyos valores recupera de la mirada nostálgica e idealizada del Perú prehispánico.

Las imágenes didácticas de la $N C$, por tanto, se adhieren a la funcionalidad didáctico-propagandística de la emblemática europea, por lo que comparten elementos compositivos similares: ambas encabezan sus imágenes con un mote (título); seguidamente, incorporan la figura (tema iconográfico discursivo principal); las dos incluyen, en ocasiones, cintas parlantes (completan el discurso iconográfico de la figura/as); ${ }^{10}$ y también ambas asocian una extensa glosa en prosa, habitualmente, en forma de sermón.

Además, la configuración de las figuras y escenas de la crónica parte de la relación topológica establecida entre icono, espacio y símbolo, resultado de la cual, subyacen dos regularidades estructurales y dos tipos de contenidos: uno dirigido al lector-observador europeo y otro al andino. Según esto, la lectura semiótica y su interpretación iconográfica permiten descubrir su composición, basada en el código artístico europeo de la iconografía cristiana y la topológica de la simbología espacial del Tarwantinsuyu inca, éste de distribución cuatripartita, organizado alrededor de un centro unificador, mediador o de síntesis. De acuerdo a los planteamientos de lectura iconográfica de Adorno (1984) y, más recientemente, de González et al. (2001 y 2003), la iconografía del cronista-artista continúa la perspectiva jerárquica dual del universo andino, basado en pares opuestos y complementarios: arriba-abajo (Hanan-Hurin), derecha-izquierda, masculino-femenino, anciano-joven, cielo-tierra. Desde este sistema dual podría entenderse la topología espacial del Tawantinsuyu, el mundo andino de los cuatro rumbos: Chinchaysuyn (Rumbo Norte), Antisuyu (Rumbo Este), Collasuyu (Rumbo Sur) y Cuntisuyu (Rumbo Oeste). La conformación de esta organización tomaría al Cuzco como centro, «ombligo del mundo», a partir del cual podría definirse el eje del par arriba-abajo del mundo terreno (Hanan-Hurin). El primer término de este par, arriba-Hanan, lo com-

10 Las cintas parlantes nominan y dramatizan la escena, aportando narratividad a la imagen en la que se integran. Pueden derivar en un verdadero diálogo entre los personajes actuantes.

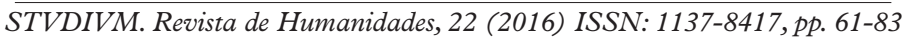




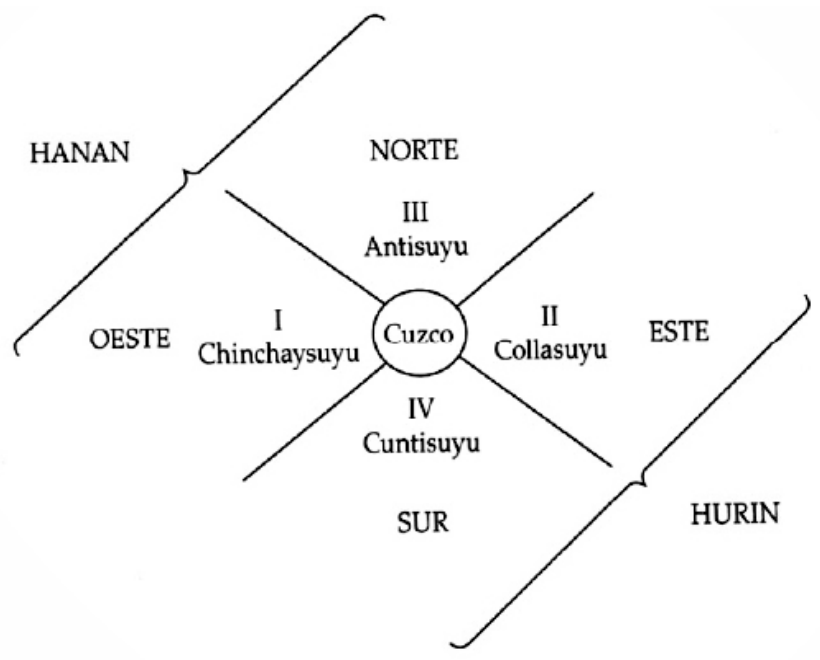

Figura 1. Topología del Tawantinsuyu.

Fuente: Ortega Sánchez (2011a: 79) y Wachtel (1973: 181)

pondría el Chinchaysuyo y el Antisuyo, mientras que el segundo, abajoHurin, estaría formado por el Collasuyu y Cuntisuyu. (Figura 1).

Según los modelos jerárquicos de pensamiento inca, los cuatro cuadrantes del Tawantinsuyu se ordenarían mediante la atribución de valores, de manera que el Antisuyu se supeditaría al Chinchaysuyu en el Hanan y el Collasuyu al Cuntisuyu en el Hurin.

Igualmente, las láminas del cronista atienden al valor posicional de pares de opuestos complementarios en los que se distinguen patrones de jerarquía, donde el primer término recibe valores más positivos que su opuesto, subordinado, por lo tanto, al primero, en la composición y lectura iconográfica. Estas relaciones, según los esquemas de pensamiento andinos, disponen y dotan de valor a los diferentes motivos que componen los dibujos, relaciones habitualmente presentadas de forma simultánea. En función de esto, encontramos patrones de jerarquía vertical con el par «arriba-abajo», el primero identificado con el mundo superior, divino, y el segundo con el terrenal y natural; de jerarquía horizontal de espacio con las relaciones este-oeste, delante-detrás, derecha-izquierda; de jerarquía horizontal de temporalidad con las relaciones de edad mayor-menor; y de jerarquía horizontal de género masculino y femenino (Tabla 1). 


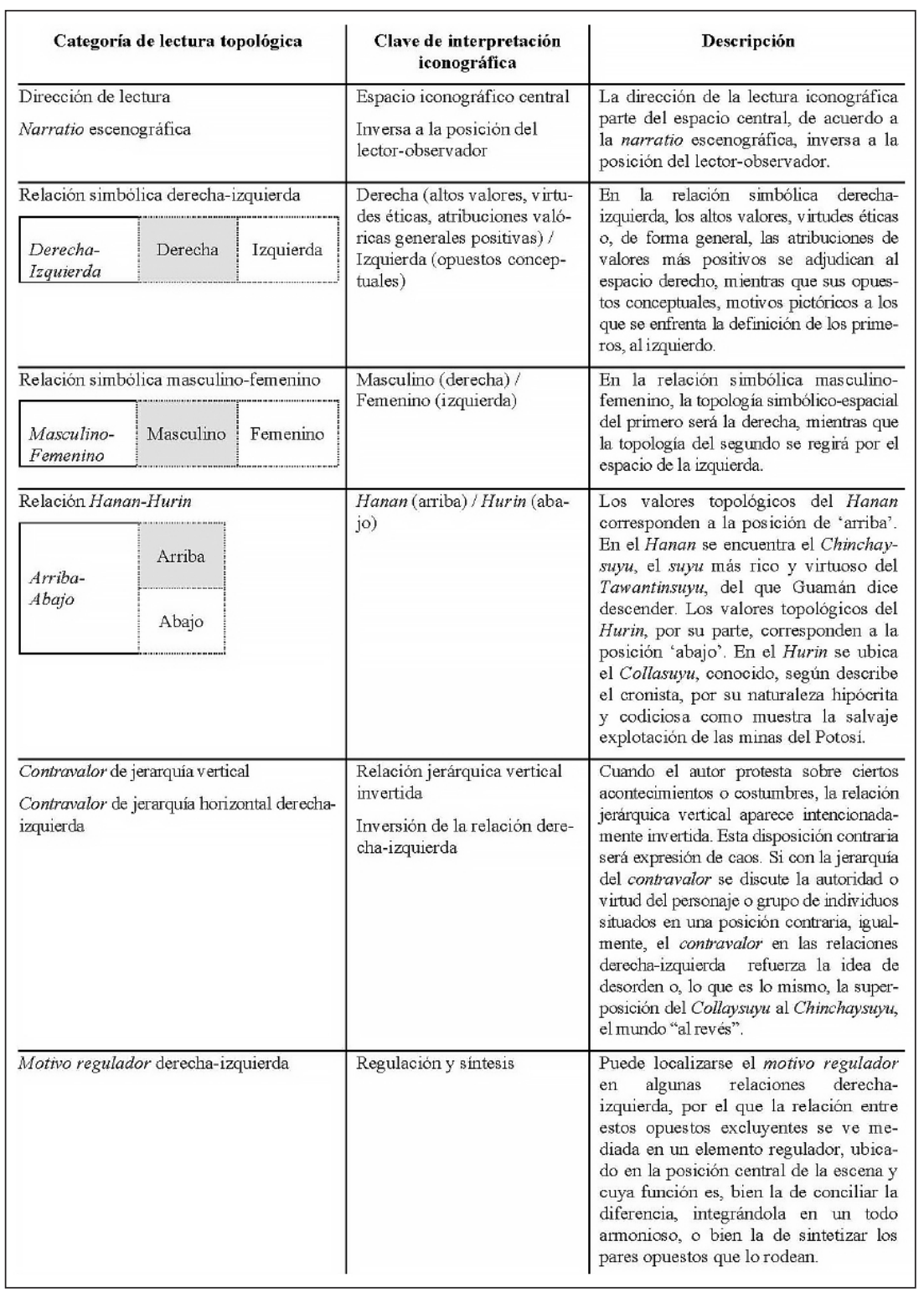

Tabla 1. Decodificación iconográfica.

Fuente: Elaboración propia 


\section{El APRENDIZAJE DE LA ESCRITURA CASTELLANA Y LA PARTICIPACIÓN EN LOS PROCESOS ADMINISTRATIVOS COLONIALES: EL INDIO LADINO}

Las órdenes religiosas, de forma individual o en colegios para hijos de caciques, seminarios y doctrinas, fueron las encargadas de impulsar las metodologías educativas y formativas de aculturación de la población nativa. En ellas, la escritura alfabética se impondría como única vía de comunicación y el español como el idioma oficial de la administración, de la justicia, de la literatura y del alto clero, razón por la que la escritura indígena en las sociedades hispanoamericanas se sumiría en un proceso de transculturación que acompañó a estas relaciones coloniales (Dueñas 2008: 189).

El aprendizaje de la lectura y escritura de la lengua castellana se presenta en la $N C$, en consecuencia, como instrumento necesario para la supervivencia y defensa de los nativos ante las autoridades virreinales. ${ }^{11} \mathrm{La}$ escritura, a la que Guamán atribuye funciones sociales específicas en el contexto colonial, opera en la $N C$ como mediador cultural responsable. En efecto, ante la necesidad de aprender la lengua y escritura castellana — conciencia de la letra-, el autor advierte su uso responsable — conciencia de la cultura- (Ortega 1988: 373-374). Los textos surgidos de este aprendizaje expresarán, por lo tanto, la transculturación del imaginario político europeo y su reformulación para la construcción intelectual e interpretación de la nueva realidad andina.

Muy representativo resulta el dibujo número uno (Figura 2), intitulado con el mote «Padres. Haze petición i nota el padre y enciste al cacique contra el corregidor o contra el mismo cacique principal para rebolbello entre ellos. Después al cabo s(e) venga del cacique y pide cohechos al cacique» (Poma de Ayala 2001: 602).

La escena representa a la autoridad nativa local, Don Juan Pilcone, quien, junto a otro indígena, formula sus quejas ante el corregidor, mientras un padre de doctrina, con suma atención y revestido con la habitual vestimenta y atributos sacerdotales, redacta el informe que habrá de ser presentado a las autoridades coloniales. En él puede leerse el texto-'cinta parlante’: «Don Juan Pilcone de Apcara, curaca camachicoc: Digo que el corregidor me pide yndio para traxeneador». Los dos indígenas mantienen

11 Ortega Sánchez 2011b; Poma de Ayala 2001: 685, 686, 758, 762, 766, 770, 784, 785, 796, $799,803,807,838,872$ y 906.

STVDIVM. Revista de Humanidades, 22 (2016) ISSN: 1137-8417, pp. 61-83 


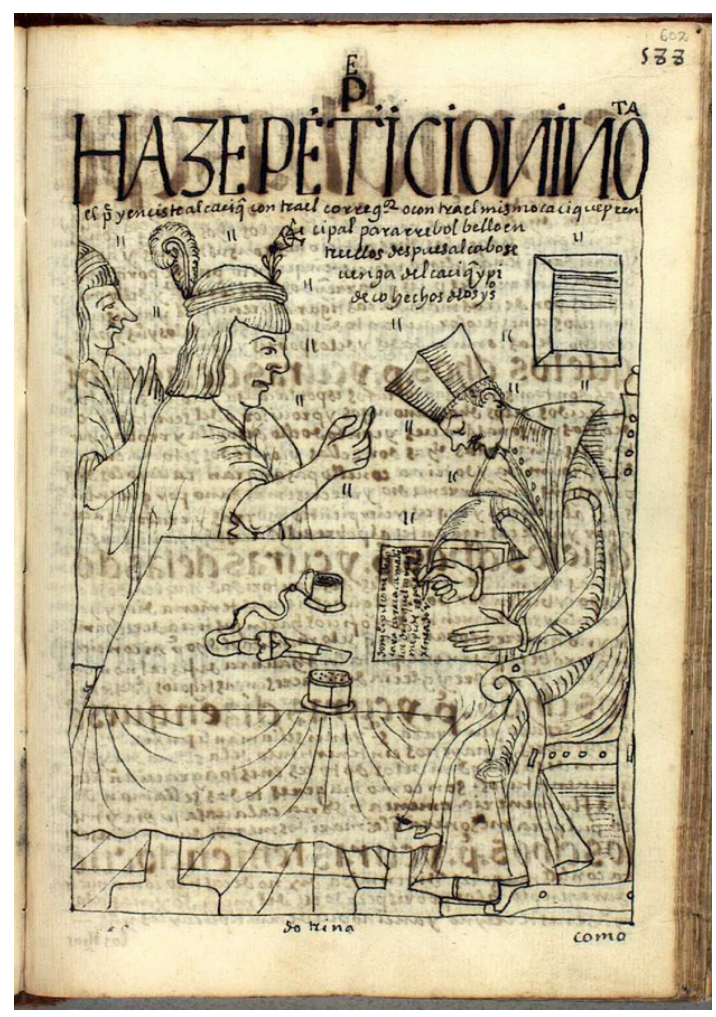

Figura 2. Denuncia de don Juan Pilcone

el dedo índice de la mano derecha levantado, signo de afirmación o alusión a un argumento de suma importancia (pronus).

La autoridad local, por su parte, aparece dispuesta de llauto, elemento de dignidad gubernamental inca, adornado con una flor en la frente y una pluma en la parte posterior. Toda la escena se desarrolla en un habitáculo de suelo embaldosado, con un pequeño vano hacia el exterior, situado en el espacio iconográfico del sacerdote.

Ambos se encuentran en espacios topológicos previsibles, según las relaciones simbólicas de lateralidad y oposición andina y el propósito de Guamán: Juan Pilcone a la derecha conceptual positiva y el padre de doctrina a la izquierda, su opuesto. Asimismo, las quejas del primero actúan como centro visual de la escena, elemento divisor de figuras antagónicas. 
Con esta imagen y la extensa glosa-comentario que la acompaña, Guamán denuncia a los padres de doctrina y la manipulación de la que son objeto las peticiones de los indios principales:

Cómo haze peticiones los dichos padres y curas de las dichas dotrinas destos rreynos o los dichos bicarios por rrebolber a los dichos corregidores con los prencipales. Hazen las dichas peticiones con sus manos y nota y mandan que tenga pleyto y encisten quanto puede porque se rrebuelba la tierra. Después queda rrey[é]ndose del corregidor y de los prencipales; por detrás manda castigar al prencipal y ancí se uengan ellos. (Poma de Ayala 2001: 603)

Son frecuentes las referencias textuales que, en combinación con las imágenes didácticas que las completan, exponen las duras consecuencias de formalizar estas peticiones y quejas contra la administración colonial, y que el autor-artista concentra en la figura del indio ladino, amerindio convertido al catolicismo y competente en el uso de la lengua y costumbres españolas. Esta figura social emplearía la nueva competencia lingüística con el objeto de ayudar en las negociaciones entre la administración colonial española y los pueblos aborígenes; esto es, el intermediario entre los primeros capitanes de la conquista y los grupos nativos, los kurakakuna, señores étnicos mediadores entre la sociedad nativa y la colonial, y los yanakuna, servidores autóctonos de patrones coloniales. ${ }^{12}$

La autoridad de esta nueva figura social en el Virreinato del Perú radicaba, no sólo en el reconocimiento de la necesidad de la escritura castellana en el orden colonial, sino también en la capacidad de conectar dos mundos a nivel lingüístico y espacial-simbólico, ofreciendo la posibilidad de participar activamente en el discurso colonial oficial.

12 A medida que se desarrollaba la interacción entre los mundos andino y español, la presencia del indio ladino como categoría o personaje tipo en la sociedad colonial se concretó en la asunción de diversos roles: líderes mesiánicos, litigantes, oficiales de la Iglesia y el Estado, escritores o acompañantes de visitadores eclesiásticos, en uso de su conocimiento y, por tanto, capacidad de detección de idolatrías, objetos asociados y rituales ancestrales. Entre estos «indios de confianza» se encontraba el propio Guamán Poma de Ayala, tal y como narra cuando recuerda al padre Cristóbal de Albornoz, juez y visitador eclesiástico, a propósito de la extirpación de las manifestaciones idolátricas del Taqui Onqoy («enfermedad de la danza») entre los años 1569 y 1571 en Huamanga. La activa participación en la vida de la administración y política colonial hace que Poma de Ayala se defina como católico a lo largo de toda la obra, y que hace coincidir con sus reales antepasados. A este respecto, consúltese Adorno (1991a y 1991b). 


\subsection{Don Cristóbal de León: icono recurrente de indio ladino}

Guamán personifica la figura del indio ladino en don Cristóbal de León, ${ }^{13}$ hijo del cacique del pueblo de San Pedro de Queca García Mullo Guama$n i$, y que frecuentemente presenta en la nuena corónica como uno de sus discípulos «cristiano(s) y ladino(s) principal(es) [y] amigo[s] de defender a los pobres». Este personaje conduce las intenciones de Guamán Poma al tiempo que le representa como parte de un grupo social privilegiado, capaz de influir en el orden colonial que condena. Será, precisamente, a partir de su figuración textual y rasgos iconográficos caracterizadores, desde donde el autor llame la atención sobre el conocimiento de la lengua y escritura española para la reclamación de derechos, y desde donde, paradójicamente, también denuncie sus negativas repercusiones causadas por las serias preocupaciones de la administración del Virreinato en torno a esta figura social. Y es que, de forma similar al criollo español, amenaza potencial por su participación en la administración colonial, el indio ladino, además, correría el peligro de ser visto por la población autóctona, sometida a vasallaje desde el acto fundacional de la conquista, como la manifestación evidente de la pérdida de los dominios andinos. En este sentido, Guamán redirige la acusación que, tradicionalmente, se dirigiría contra el indio ladino de utilizar sus competencias interculturales para la falsificación de informaciones en su beneficio, hacia el funcionario y religioso español, temeroso de que pudieran ser descubiertos sus desórdenes. En este punto, Guamán relata la persecución de la que fue objeto Cristóbal de León por el corregidor de Lucanas, quien le apresó, castigó en el cepo, quemó su casa y desterró por haber formalizado quejas contra esta administración.

Explícitamente, en la escena del dibujo, intitulado con el mote "Q[ue] el comendero le haze ahorcar al cacique prencipal don Juan Cayan Chire y por dalle contento al encomendero le cuelga el corregidor» (Poma de Ayala 2001: 571) observamos tres personajes: Juan Cayan Chire, cacique principal ajusticiado, un corregidor y un encomendero (Figura 3). Las disposiciones espaciales de los personajes y la lectura de sus gestos aportan las claves interpretativas que el autor completa en la glosa de la lámina: el nativo se encuentra bien ubicado a la derecha, mientras el corregidor y el

13 La etimología de su nombre y apellido han hecho pensar a los estudiosos en la experiencia vital del propio cronista y en la conexión de las dos cosmovisiones culturales, la occidental y la andina: «Cristóbal» (servidor de Cristo) de «León» (servidor de león, puma).

$\overline{\text { STVDIVM. Revista de Humanidades, } 22 \text { (2016) ISSN: 1137-8417, pp. 61-83 }}$ 


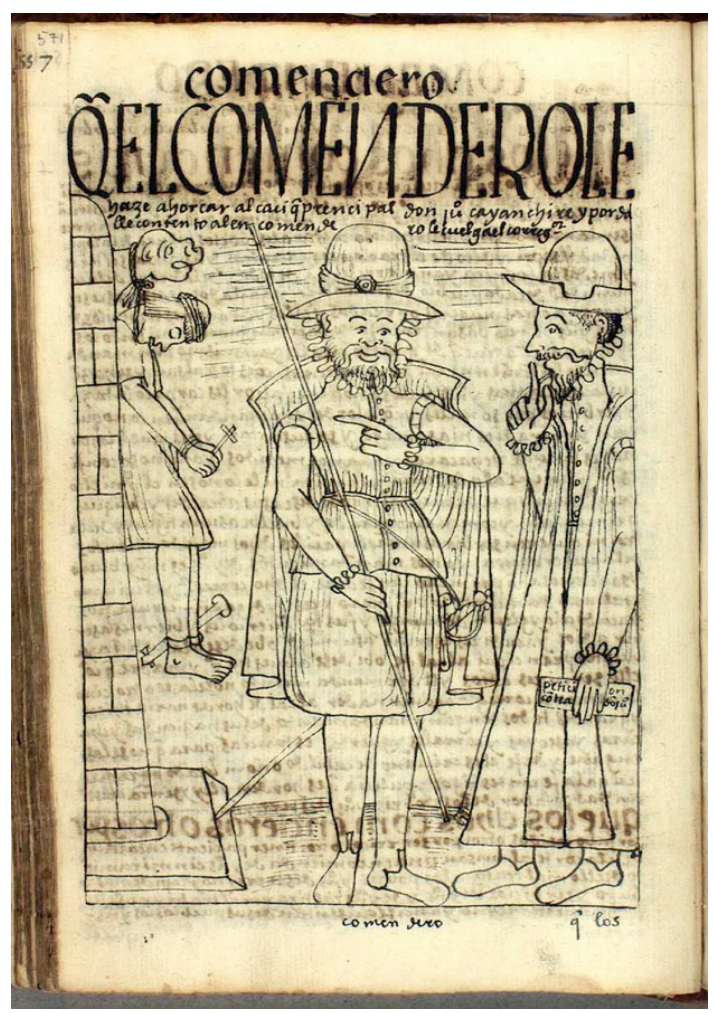

Figura 3. Ajusticiamiento del cacique Juan Cayan Chire

encomendero ocupan el espacio central e izquierdo, respectivamente; el corregidor porta el atributo de su cargo, la vara, y el encomendero una orden de ajusticiamiento en su mano izquierda, en cuyo encabezado puede leerse: «petición contra don Juan».

El tamaño de las figuras españolas es desmesurado, recurso frecuente en el artista para expresar dominio y poder sobre el nativo. El corregidor, elegantemente vestido con espada al cinto y sonrisa satisfecha, muestra al encomendero, señalando con su mano izquierda, signo de indignidad, el cumplimiento de la ejecución. De igual modo y actitud, el encomendero pide silencio al corregidor sobre la sentencia y ejecución. Mientras tanto, la autoridad local aparece con las manos unidas sosteniendo un crucifijo, muestra de fe y expresión de injusticia. 
Con esta imagen se recriminan los abusos de los principales funcionarios reales, concretados en ajusticiamientos en los que el encomendero o el padre de doctrina solicitan al corregidor el ajusticiamiento del cacique principal, acusado de presentar una defensa legal. Como observamos en el dibujo, satisfecha la demanda, el encomendero hace un ademán de silencio con la mano derecha; la relación de este silencio con el indio ahorcado es clara, pues Guamán la codifica en la figura del corregidor, guiando al lector-observador en la lectura final de la imagen. En la glosa a la imagen didáctica, Poma se refiere al castigo de don Cristóbal de León quien, al igual que la autoridad local, fue perseguido por la defensa de derechos:

Que los comenderos son enemigos mortales de los caciques prencipales porque a de defender a los yndios. Y ací procura que todos muera ahorcado. Y el dicho corregidor lo ahorca o lo castiga, afrenta por dalle contento al encomendero y al padre de la dotrina, como le ahorcó a don Juan Cayan Chire, cacique prencipal, y a don Pedro Poma Songo de Luri Cocha, murió preciguido. Don Diego Tiracina de Banbo se murió preciguido. Y don Cristóbal de León fue afrentado y castigado. (Poma de Ayala 2001: 572)

El rechazo a la «ladinidad» por su capacitación para participar en el sistema jurídico colonial se manifiesta, de forma específica, en los dos siguientes dibujos (Figuras 4 y 5), donde se representa el apresamiento del discípulo de Guamán, motivo iconográfico recurrente en diversos dibujos de la NC.

En la primera imagen, intitulada «Correg[id]or tiene preso y amolestado a don Cristóbal de León, segunda persona, porque defendió a los yndios de la prouincia» (Poma de Ayala 2001: 498), los planos espaciales verticales que componen esta escena de un interior embaldosado se separan con la idea de enfatizar la división entre la defensa de los nativos, que lidera Cristóbal de León, y la injusticia, administrada por el corregidor (Figura 4). Para reforzar esta lateralidad vertical, el autor-artista dramatiza un pequeño diálogo entre el funcionario real y el apresado con dos textos'cintas parlantes', uno redactado entre las dos composiciones iconográficas verticales: «Uarcuscayqui galeraman carcoscayqui, pleyista vellaco yndio» (te voy a colgar, te voy a expulsar a las galeras, pleitista bellaco indio); y otro en la madera del cepo del ladino: «Runayrayco cay sepopi nacarisac» (por mi gente, voy a sufrir en este cepo). A la derecha conceptual, el indio ladino acepta con resignación el injusto castigo en un cepo que inmoviliza sus piernas. En actitud de oración y sujeto con grilletes en manos y pies, aparece elegantemente vestido al estilo español con sombrero, capa y gola. A su izquierda conceptual opuesta, se coloca al funcionario 

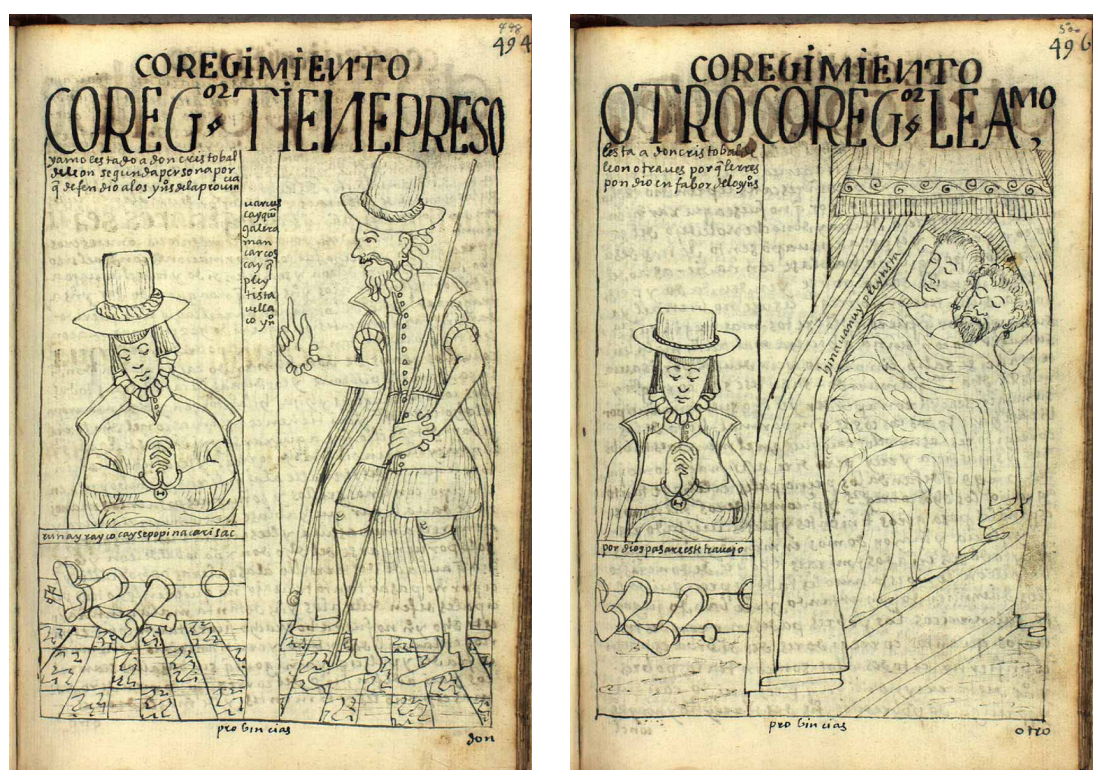

Figuras 4 y 5. Don Cristóbal de León, apresado por el corregidor

quien, igualmente vestido, porta la vara de su cargo con la mano izquierda, gesto que radicaliza la inmoralidad del mandatario. Además, levanta el dedo índice, gesto iconográfico utilizado, como apuntábamos, para la expresión de contenidos relevantes.

De acuerdo al mote de la imagen y al comentario-glosa que la acompaña, el castigo fue impuesto por el corregidor de la provincia de Lucanas por la negativa de Cristóbal de León a la entrega de indios para «tragenear» y su reclamación ante el Virrey (Poma de Ayala 2001: 499).

Directamente relacionado con esta escena, el segundo dibujo (Figura 5) representa lo que hubiera podido constituir otro de los momentos acaecidos durante el proceso de apresamiento del discípulo del autor de la crónica, bajo el mote: «Otro correg[id]or le amolesta a don Cristóbal de León otra ues porque le rrespondió en fabor de los yndios» (Poma de Ayala 2001: 500). La distribución compositiva de los iconos que configuran la imagen mantiene la separación de espacios independientes verticales. Cristóbal de León, acusado, según la glosa a la imagen, de no haber cedido a la entrega de «yndios trageneadores» ni prestarse a tejer e hilar, conserva la actitud resignada y orante, mientras el corregidor, al que 
Guamán retribuye con los calificativos de «asno del corregidor», «bobo de los corregidores», «asno de los caciques en el mundo» (Poma de Ayala 2001: 501), duerme plácidamente con su mujer. La sentencia-'cinta parlante', que el autor suscribe en la cortina de la cama del mandatario virreinal, desvela la clave de lectura: «Hina uanuy, pleytista» (muere así pleitista), y a la que el ladino responde con el texto de su cepo: «Por Dios pasaré este travajo». Con ella, se representa la animadversión de las autoridades hacia el uso del indio ladino en los procesos legales. En cuanto a las relaciones espaciales, éstas se corresponden con las del dibujo anterior: Cristóbal de León a la derecha y el corregidor y su mujer, a la izquierda conceptual.

Esta conciencia didáctica y persuasiva de las relaciones entre palabra e imagen se revela en la misma glosa de la imagen con la frase "Mira este pobre de don Cristóbal de León, cómo está amolestado y preciguido, ellos duermiendo y hurtando y rrobando, jugando, salen rricos. Los pobres padesen grandes trauajos» (Poma de Ayala 2001: 501). La señalización de lugar (el dibujo), el imperativo «mira» y el deíctico «este» junto a los calificativos «pobre», «amolestado» y «preciguido» —elementos retóricos que buscan animar las pasiones del lector-, manifiestan la asunción, por parte del artista, de los principios tridentinos sobre la conveniencia del uso de imágenes en la predicación (López-Baralt 1988: 124-125 y 171-185), y de los mecanismos pictórico-sensoriales ignacianos.

\section{El PADRE DE DOCTRINA Y EL MAESTRO, ¿OBSTÁCULOS DE APRENDIZAJE?}

A pesar de la existencia de colegios para nativos y escuelas parroquiales en el Cuzco, Quito y Lima, es evidente el desinterés de encomenderos, corregidores y padres de doctrina por la enseñanza a los indígenas (Navarro 2003), motivado, según el autor de la crónica, por el hecho de que los niños no supieran «pleytos y hordenansas»:

Que los dichos corregidores y padres y comenderos quieren muy mal a los yndios ladinos que sauen leer y escriuir, y más ci sauen hazer peticiones, porque no le pida en la rrecidencia de todo los agrauios y males y daños. Y ci puede, le destierra del dicho pueblo en este rreyno. (Poma de Ayala 2001: 493)

A este desinterés se añadía el castigo corporal, constantemente denunciado en el manuscrito y especialmente centrado en el padre de doctrina, responsable último de la educación catequética (Figura 6) y básica (Figura 7). 


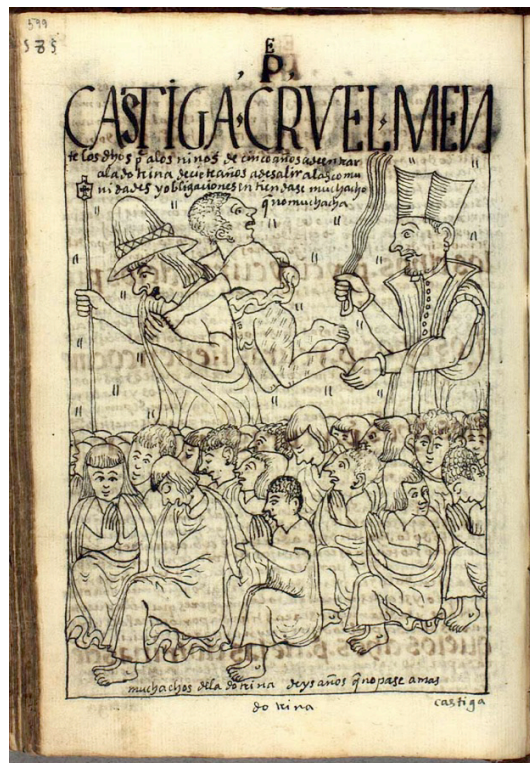

Figura 6. Castigos

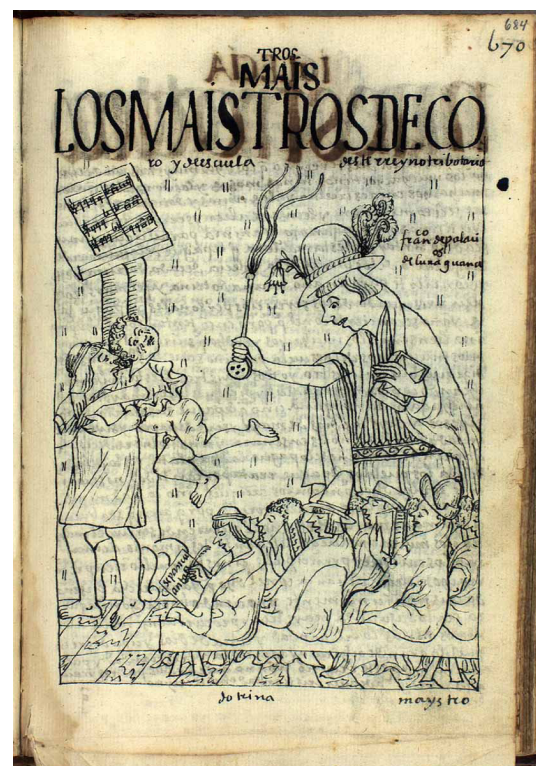

Figura 7. Maestros de coro y de escuela

En la Figura 6, con el mote "Castiga cruelmente los dichos padres a los niños. De cinco años a de entrar a la dotrina, de ciete años a de salir a las comunidades y obligaciones; entiéndase muchacho que no muchacha» (Poma de Ayala 2001: 599), dos planos horizontales se superponen: uno inferior, dedicado a un grupo de niños en actitud orante, y otro superior, a la representación de la agresión con látigo de un sacerdote a un niño desnudo, marca de vulnerabilidad. ${ }^{14}$ La disposición simbólica de estos dos planos se rige por la superioridad de uno sobre el otro; el superior alberga las figuras con una función regidora sobre el plano inferior, subyugado, por tanto, a las normas del primero. Asimismo, el plano superior se subdivide en otros dos opuestos: el derecho, ocupado por el pequeño que, ataviado con un

14 Para Guamán, el desnudo sin genitales expresa vulnerabilidad, inocencia, moralidad primigenia. Así representa a Adán y Eva en «Dios crea el mundo y se lo entrega a Adán y Eva» (Poma de Ayala 2001: 12) y así lo repite cuando denuncia los abusos españoles e incas a los nativos. Si, por el contrario, se representan los órganos sexuales y, de forma exagerada, en las nativas, la idea transmitida refiere «complicidad» con la corrupción colonizadora en Indias. En el caso de los indios varones, implica una relación de vulnerabilidad con los desmanes hispanos (Ortega Sánchez 2011a). 
camisón (unku) arremangado, dirige su mirada horrorizada hacia atrás, y el nativo adulto principal que lo carga; y el izquierdo, signo de injusticia e indignidad, en el que sitúa a un religioso de vestiduras clásicas y rostro violento sujetando, con su mano izquierda, el pie de un niño, mientras arremete, con la derecha, contra el mismo. El nativo principal mantiene una dirección de marcha hacia la derecha, mano con la que también sostiene su vara de mando, ésta terminada en una cruz, muestra de su cargo de fiscal.

En la glosa, nuestro autor protesta por los crueles castigos a los que son sometidos los niños y recuerda la obligación educativa de los padres de doctrina:

Castiga cruelmente los padres de las dotrinas a los niños. Aunque le está mandado en las hordenansas de don Francisco de Toledo, bizorrey, y confirmado de su Magestad y en el Santo Concilio, los muchachos de cinco años entren a la dotrina y de ciete años salga a las comunidades. (Poma de Ayala 2001: 600)

A la crítica contra esta metodología, el cronista une la invectiva contra la ignorancia de algunos maestros de coro, ${ }^{15}$ su entrega al vino y a la violencia, presente en la Figura 7 con el mote «Maistros: los maistros de coro y de escuela deste rreyno tributario» (Poma de Ayala 2001: 684). La disposición espacial de los motivos iconográficos, en este caso desarrollados en una escena de interior de suelo embaldosado, se asemeja a la del dibujo anterior, precisamente un marco escénico que Guamán recupera para argumentar y dejar constancia visual de su denuncia. En la presente imagen, el espacio simbólico se subdivide en dos planos conceptuales verticales: uno derecho superior, donde se sitúa la partitura musical de la lección; otro derecho inferior, en el que se ubica al niño agredido, cargado por un sirviente nativo, como representación simbólica de la supeditación del castigo al valor de la enseñanza; y uno izquierdo negativo, dedicado al maestro en actitud de agresión. Por último, puede reconocerse un tercer plano, éste de disposición horizontal inferior, supeditado al superior, donde se ubica la autoridad del maestro. En éste se representa a un conjunto de discípulos sentados en un banco corrido: concentrados en la lección, no dirigen su mirada ni al maestro ni al niño castigado, sino que continúan, como muestra uno de los alumnos, con las notas de la lección dictada.

La figura de maestro, acompañada del texto-'cinta parlante': «Francisco de Palacios de Luna, Guanca», en este caso, meramente nominativa,

15 Acerca de la música y su valor en la conformación de identidades en el Virreinato del Perú, puede consultarse el estudio de Véliz (2008). 
aparece provista de un sombrero con tres plumas en la parte trasera y una flor en la delantera, un amplio camisón (unku), pantalón y una especie de capa. Con la mano izquierda aprieta para sostener el libro de lecciones y con la derecha empuña el látigo.

A pesar de identificarse la figura del maestro con Francisco de Palacios y Luna, la glosa textual nos habla del maestro Damián, indio de Santiago de Huayanay, quien, tras haber recibido las costas por el ejercicio de su magisterio y por consentimiento del sacerdote, no cumplió su cometido:

[...] En todo el año no le enseñó a los muchachos de la dicha escuela ni sauía la dotrina. Todos los días estaua borracho, perdido y uellaqueando y ganando salario por el gusto del padre a costa de los yndios. (Poma de Ayala 2001: 686)

\section{Conclusiones}

La nueva evaluación de los textos indígenas sobre la conquista y colonización del Nuevo Mundo ha puesto de manifiesto la existencia de procesos de transculturación, entendidos como actos de traducción dialógica entre visiones cosmológicas incompatibles y los nuevos sistemas de codificación cultural. En este sentido, la cuidadosa configuración iconográfica de los dibujos de Guamán representa el resultado del conocimiento consciente de la utilidad y potencial didáctico, persuasivo, propagandístico y mnemotécnico de la imagen (Chang-Rodríguez, 2005). Las más de mil páginas de la Primer nueva corónica y buen gobierno se aproximan a la cultura didáctico-visual europea del momento al establecer relaciones directas entre el discurso verbal y el iconográfico, al tiempo que mantienen los principios simbólico-espaciales de la cosmovisión andina en un particular diseño discursivo de trescientas noventa y ocho «imágenes memorativas». De este modo, mediante la utilización de la escritura y de la imagen, Guamán Poma, conocedor de las lenguas amerindias y española, aúna, sin exclusiones, el saber tradicional andino y el cultural europeo con el objeto de explicar, en un discurso identitario completo, la realidad colonial. Además, utilizará su status como indio ladino para ejercer como mediador cultural de dos mundos, el propio de su identidad andina y el colonial europeo.

En definitiva, Guamán sitúa en la lengua, la escritura y la educación colonial el germen del orden político y administrativo. El dominio de la escritura fija la base para la conformación de una identidad múltiple y transcultural no excluyente, que evidencia la comunicación dialógica y efectiva de una memoria cultural, resultado de la negociación de dos iden- 
tidades, la propia de la conciencia del pasado prehispánico y su recodificación ordenada en los patrones culturales europeos. No puede hablarse, por tanto, de la prueba evidente de una aculturación que supone la incorporación total de la cultura de origen a la advenediza, tampoco de mestizaje, promovido por la ideología de la «integración» que diluye la identidad aborigen en la colonial, sino de un pluralismo cultural en distinto grado de sincretismo (Ortega 1988: 366).

\section{REFERENCIAS BIBLIOGRÁFICAS}

\section{Ediciones}

Poma De Ayala, Felipe Guamán, 2001, Primer nuena corónica y buen gobierno. Revisión académica de Rolena Adorno). Edición digital facsímil. Copenhaguen, Royal Library of Denmark. Disponible en: http://www.kb.dk/permalink/2006/poma/info/es/frontpage.htm

\section{Estudios}

Adorno, Rolena e Iván Boserup, 2003, New Studies of the Autograph Manuscript of Felipe Guaman Poma de Ayala's Nueva corónica y buen gobierno. Copenhague, Museum Tusculanum.

ADORNO, Rolena, 2000, «Contenidos y contradicciones: la obra de Felipe Guaman Poma y las aseveraciones acerca de Blas Valera», Ciberletras: Revista de crítica literaria y de cultura 2. En línea: <http://www.lehman.cuny.edu/ciberletras/ v01n02/Adorno.htm>

ADORNO, Rolena, 1991a, «Nosotros somos los kurakakuna. Imágenes de Indios Ladinos.» En Kenneth J. Andrien y Rolena Adorno, eds., Transatlantic Encounters. Berkeley, University of California Press, 232-272.

ADORNo, Rolena, 1991b, «La visión del visitador y el indio ladino.» En Raquel Thiercelin, ed., Cultures et sociétés Amdes et Méso-Amérique Mélanges en hommage à Pierre Duviols. Aix-en-Provence, Université de Provence, 35-50.

Adorno, Rolena, 1991c, Guaman Poma. Literatura de resistencia en el Perú colonial. México DC, Siglo XXI.

Adorno, Rolena, 1984, «Paradigmas perdidos: Guamán Poma examina la sociedad española colonial», Revista Chungará, 13, 67-91.

CANTÙ, Francesca, 2001, Guaman Poma y Blas Valera. Tradición Andina e Historia Colonial. Roma, Antonio Pellicani Editore.

Chang-Rodríguez, Raquel, 2005, La palabra y la pluma en 'Primer nueva corónica y buen gobierno'. Lima, Fondo Editorial de la Pontificia Universidad Católica del Perú. 
DueÑAs, Alcira, 2008, «Fronteras culturales difusas: autonomía étnica e identidad en textos andinos del siglo XVII», Bulletin de l'Institut Francais d'Études Andines, 37 (1), 187-197.

FriTZ, Sabine, 2005, «Guamán Poma de Ayala como traductor indígena de textos culturales: La Nueva Corónica y Buen Gobierno (c. 1615)», Fronteras de la Historia, 10, 83-107.

Galino Carrillo, M. Ángeles, 1948, Los tratados sobre educación de príncipes (siglos XVI y XVII). Madrid, CSIC.

GonzÁlez Boixo, José Carlos, 1999, «Hacia una definición de las crónicas de Indias», Anales de Literatura Hispanoamericana, 28, 227-237.

González Vargas, Carlos, Hugo Rosati Aguirre y Francisco Sánchez CabeLLO, 2003, Guamán Poma. Testigo del mundo andino. Santiago de Chile, LOM Ediciones/Centro de Investigaciones Barros Arana.

González Vargas, Carlos, Hugo Rosati Aguirre y Francisco Sánchez CabeLLO, 2001, «Sinopsis del estudio de la iconografía de la Nueva corónica y buen gobierno escrita por Felipe Guaman Poma de Ayala», Historia, 34, 67-89.

LÓPEZ-BARAlt, Mercedes, 1988, Icono y conquista: Guaman Poma de Ayala. Madrid, Hiperión.

NaVArro Gala, Rosario, 2003, Lengua y cultura en la 'Nueva corónica y buen gobierno'. Aproximación al español de los indígenas en el Perú de los siglos XVI y XVII. Valencia, Universitat de València.

Ortega, Julio, 1988, «El cronista indio Guaman Poma de Ayala y la conciencia cultural pluralista en el Perú colonial», NRFH, XXXVI (1), 365-377.

Ortega SÁnchez, Delfín, 2011a, Sociedad, Política y Religión en el Virreinato del Perú. La subversión del orden colonial en la 'Primer nueva crónica y buen gobierno’ (1615-1616) de Guamán Poma de Ayala. Cáceres, Universidad de Extremadura.

ORTEGa SÁnchez, Delfín, 2011b, «El indio ladino en la emblemática política de la Primer nueua corónica y buen gobierno (1615-1616): El caso de don Cristóbal de León.» En Rafael Zafra y José Javier Azanza, coords., Emblemática trascendente: hermenéutica de la imagen, iconología del texto. Pamplona, Universidad de Navarra, 595-606.

ORTEga SÁnCHEZ, Delfín, 2010, «La Primer nueva corónica i buen gobierno de Guamán Poma de Ayala (1615-1616): un estudio desde la emblemática política europea y la topología andina.» En Jesús Luque, M. ${ }^{a}$ Dolores Rincón e Isabel Velázquez, eds., Dulces camenae. Poética y poesía latinas. Jaén-Granada, Universidad de Granada, 629-640.

OrTega SÁnchez, Delfín, 2009, «Palabra, Imagen y Símbolo en el Nuevo Mundo: de las imágenes memorativas de fr. Diego Valadés (1579) a la emblemática política de Guamán Poma de Ayala (1615)», Noua Tellus, 27 (2), 19-70. 
Pérez Cantó, M. ${ }^{a}$ Pilar, 1996, El buen Gobierno de Don Felipe Guaman Poma de Ayala. Cayambe, Abya-Yala.

Pezzuto, Marcela, 2006, «Una lectura de la tradición humanista en el discurso de Nueva Corónica y Buen Gobierno de Felipe Guamán Poma de Ayala», Moenia, 12, 225-241.

Porras BarrenecheA, Raúl, 1999, Obras completas de Raúl Barrenechea, I. Indagaciones peruanas. Lima, Universidad Nacional Mayor de San Marcos-Fondo Editorial e Instituto Raúl Porras Barreneachea.

SERnA ANÁIZ, Mercedes, 2012, «La política colonial en las obras del Inca Garcilaso de la Vega y de Guaman Poma de Ayala», Anales de Literatura Hispanoamericana, 41, 99-120.

Véliz CARTAgena, Mauricio, 2008, «Un lugar en el mundo: palabras, saberes musicales e identidad en el Perú del siglo XVII», Histórica XXXII (1), 77-113.

WACHTEL, Nathan, 1973, «Pensamiento salvaje y aculturación.» En Nathan Wachtel, aut., Sociedad e ideología. Ensayos de historia y antropología andinas. Lima, Instituto de Estudios Peruanos, 165-228. 